\title{
The Application of Classroom Interaction in English Lesson
}

\author{
Xiaolin Jia \\ Foreign Language School, Jilin Institute of Chemical Technology, \\ Jilin City, Jilin Province, 132000, China \\ E-mail:jiaxiaolin1982@163.com
}

Keywords: Classroom; Interaction; English Teaching

\begin{abstract}
Due to the level of China's English education and the large use of the traditional teaching method, there are many difficulties in using classroom interaction. This paper analyzes the factors affecting classroom interaction and gives the teachers some suggestions to achieve classroom interaction in EFL teaching in order to make some contributions to the education reform, English teaching and research.
\end{abstract}

\section{Introduction}

In the practice of our English language teaching and learning, lack of interaction is a common thing. As a matter of fact, most college EFL teachers in China are confronted with awkwardness: most of the learners sit looking straight ahead and use minimal facial expressions, gestures and verbal utterances; most of the learners seldom ask questions, make comments and respond with nods and shakes of the head, with the sounds of agreement or sounds of understanding; some learners always keep their heads down and remain silent when asked questions or assigned to group work. Therefore, this paper focuses on the reasons of lacking of interaction in foreign language teaching, and puts forward the strategies for implementing classroom interaction.

\section{Understanding of Classroom Interaction}

The classroom interaction has three components. It provides learners with opportunities both to encounter input and to practice the L2. It also creates in the learners "a state of receptivity," defined as "an active openness, a willingness to encounter the language and the culture it represents." [1]

According to the participants in classroom interaction: the teacher and the learners, classroom interaction is classified into two categories: teacher-learner interaction, learner-learner interaction.

Teacher-learner interaction has broad sense and narrow sense. In broad sense, teacher-learner interaction is the interaction between the teacher and learner. In narrow sense, it is the interaction between the teacher and learner or the teacher and learners in teaching situation.

Learner-learner interaction is based on peer relationships, which allows the maximum degree of communication [5]. Carefully structured learner-learner interactions provide a forum for extended, meaningful exploration of ideas, which exposes learners to more varied and complex language from their peers than does traditional teacher-fronted classroom interactions. Through interaction with other learners in pairs or groups, learners can have more opportunities to make use of linguistic resources in a relaxing and uncontrolled manner and use them to complete different kinds of tasks.

According to the focus point of learner's language competence and the benefit of learner activities, there are two types of classroom interaction: language output and language input. Language output mainly concerns foreign learners' competence of using language. Language input aims to improve learners' mastering of target language and speed up their language acquisition. Classroom interaction tends to be scientific and diverse. 


\section{Factors Affecting Classroom Interaction}

What factors will affect classroom interaction? The following factors are needed in classroom interaction in foreign language teaching. In other words, the following factors are what are needed for improving English teaching in English class.

A. Teachers' beliefs

Shavelson indicates that teacher's theoretical beliefs, guiding teachers' expectations and decisions are thought to act as filters through which teachers make instructional judgments and decisions. Teachers' beliefs are instrumental in shaping how teachers interpret what goes on in their classrooms and how they will react and respond to it [12]. Their beliefs evolve from what Lortie characterized as the apprenticeship of observation and based on early experiences as learners. When teachers enter teacher education programs, they bring with them an accumulation of prior experiences that manifest themselves in the form of beliefs that tend to be quite stable and rather resistant to change [10]. Some attribute this inflexibility, in part, to teachers' lack of knowledge about how to adjust their beliefs to the realities of life in classrooms [4]. Numerous studies in the fields support the notion that teachers teach in accordance with their beliefs.

B. Teachers' Questions

Questioning plays a significant part in classroom teaching. Questions stated in language that is too complex or too wordy for aural comprehension. Teachers' questions should provide necessary methods to communication, attract learners' attention, and learn about the extent of learners' comprehension, help learners understand puzzlement and know what is important, provide learners with opportunities to find out what they think by hearing what they say. However, asking a lot of questions in classroom will guarantee stimulation of interaction. Certain types of questions may actually discourage interactive learning. Therefore, it is unlikely for the EFL teacher to ask only either of the two questions types. The teacher should choose the types according to the different proficiency level of learners. The higher the English proficiency level the learners are in, the more the teacher can venture into asking referential questions. So the teacher should challenge their learners sufficiently but without overwhelming them. And in the following part, learners' different English levels will be discussed.

C. Learners' Different English Levels

Teachers of English generally make three basic level distinctions: beginner, intermediate and advanced (though exactly what these terms mean often depends where you work and what textbook you are using). Broadly, however, beginners are those who don't know any English and advanced learners are those whose level of English is competent, allowing them to read unsimplified fact and fiction and communicate fluently, with native speakers. Between these two extremes, intermediate suggests basic competence in speaking and writing and an ability to comprehend fairly straightforward listening and reading. .

D. Teacher-learner Rapport

"Rapport" is a somewhat slippery but important concept increasing positive climate in the classroom. Rapport here is the relationship or connection the teacher establishes with their learners, a relationship that is built on trust and respect and that leads to learners' feeling capable, competent, and creative. Part of the rapport is created on the delicate balance that is set between praise and criticism. Too much of either one renders it less and less effective. Genuine praise enables students to welcome criticism.

E. Anxiety

MacIntyre and Gardner looked in more detail at anxiety seem to relate to negative experiences in speaking activities. This would confirm the experience of many teachers, but the suggestion that arises from such studies, that anxiety is a response learned through early experiences and that it can increase until the whole process of learning is badly affected, emphasizes the need for 'humanistic' approaches in the widest sense of the word [11]. It implies that teaches have both the power and the responsibility to counter the development of anxiety by building self-confidence through positive 
early experiences, through providing reassuring feedback, and through promoting self-perception of developing proficiency.

\section{Strategies of Promoting Classroom Interaction}

\section{A. Improving Questioning Strategies}

Actually many learners are not confident of themselves in an English class and they are afraid of losing face before their peers. In such a situation, the teacher's interaction with individual learners is based on his own selection. In addition, he tends to ask active ones to answer questions. This inevitably discourages poorer or inactive learners. To activated the teacher-learner interaction and ensure all learners participate; attention should be paid to the protection of learners' self-esteem and the development of their self-confidence. It is preferable to ask learners questions that they can answer. While questioning, it is necessary for the teacher to tailor his questions to the different levels or abilities of the learners.

B. Attending to Learners' Linguistic Levels

One obvious difference in the way we teach different levels is language. Beginners need to be exposed to fairly simple language which they can understand. Intermediate learners know all this language already and so well not ask them to concentrate on it.

The activities we offer learners often depend on their language level. For beginners, we will not suggest abstract discussions. For advanced learners, a drill focusing on simple role-play with ordinary information questions may be a good target for beginners to aim at; the focus or advanced learners will have to be richer and more subtle. Teachers react both overtly and subconsciously to different levels. The material they are use-and the activities they are get learners to engage inreflect the unique needs of those learners at the level they have reached.

C. Implementing Cooperative Learning

Working cooperatively not only helps learners develop important social skills, it is an excellent way to help them relate appropriately to others with backgrounds different from their own. Learners with varied social backgrounds, intellectual skills, and physical capabilities work together to learn subject matter, solve problems, and accomplish tasks. They learn to accept and value individual differences. Cooperative learning means that every member of the group is included, and differences among group members are resolved by the group members. Further, group members work toward solving problems and completing tasks within minimal teacher assistance. The social skills that group membership develops are critical to life within and beyond the classroom.

D. Building Positive Teacher-learner Rapport

In order to make classroom interaction more effective, the importance of the relationship between the teacher and the learners cannot be overestimated. A good teacher ought to know his learners well, for having knowledge and understanding of the learners' background provides an important basis for the teacher's planning at each steps of the teaching process. A sound relationship needs to be established on the basis of mutual respect between the teacher and the learners. Respect for people is considered as an essential part of education and the most important contributors to good rapport between the teacher and the learners.

As a result, both the teacher and the learners will become equally responsible for themselves and the class. The more harmonious the relationship between the teacher and the learners grows, the more conspicuous the dynamic qualities of classroom learning become.

E. Reducing Classroom Anxiety

In EFL classrooms, learners are reluctant to speak out in English, and to participate in the classroom interaction with the teacher, or even with their classmates, owing to their personality types and their cultural backgrounds, their English proficiency, their interest in the teaching materials and classroom activities, to name just a few. The teacher should help learners understand that language anxiety episodes can be transient and do not inevitably develop into a lasting problem, boost the self-esteem and self-confidence of learners for whom language anxiety has already 
become a long-term trait by providing multiple opportunities for classroom success in the language, and encourage moderate risk-taking and tolerance of ambiguity in a comfortable, non-threatening environment.

\section{Conclusion}

Classroom interaction is vital to improve the effect of language classroom teaching and learning. It is hoped that these methods will be used in further English language teaching and will guide English teacher applying in their teaching. Moreover, the paper hopes to reduce the gaps between theories and practice and to be useful to the perfection of our country's English teaching.

\section{References}

[1] Arnold, J., Affect in Language Learning, Cambridge: Cambridge University Press, 1999.

[2] Bailey, K. M., "Competitiveness and Anxiety in Adult Second Language Learning: Looking at and Through the Dairy Studies’ in H. D.”, Brown and S. Gonzo (eds.) , 1995.

[3] Cathcart, R., "Situational Differences and the Sampling of Young Children's School Language”, In Day (ed.), 1986.

[4] Calderhead, J. \& Robson, M. Images of Teaching: Student Teachers' Early Conceptions of Classroom Practice. Teaching and Teacher Education. 7: 1-8., 1991.

[5] Comeau, F. R. Interactive Oral Grammar Exercises, Beijing: People’s Education Press, 2000.

[6] Ellis, R. The Study of Second Language Acquisition. Oxford: Oxford University Press, 1994.

[7] House, J., "Learning No Talk: Taking to Learn An Investigation of Learner Performance in Two Types of Discourse”, In Kasper (ed.), 1986.

[8] Jeremy, H., How to Teach English. Beijing: Foreign Language Teaching and Research Press, 2000.

[9] Johnson, K. E., “Teacher Education”, Teacher of English to Speakers of Other Languages, Inc, 2000.

[10] Lortie, D. Schoolteacher: A Sociological Study. Chicago: University of Chicago Press, 1975.

[11] MacIntyre, P. D. \& Gardner, R. C. Language Anxiety: Its Relation to Other Anxieties and to Processing in Native and Second Languages. Language Learning. 41(4): 513-34, 1991.

[12] Shavelson, R. J. Review of Research on Teachers' Pedagogical Judgment, Plans, and Decisions. Elementary School Journal. 83:392-413, 1983. 